\title{
A QUAGMIRE OF PAROCHIALISM: THE ETHICS OF REFUGEE CHILDREN'S EDUCATION
}

\author{
Kalyanasis Bhattacharyya \\ Government General Degree College at Keshiary, Paschim Medinipur, India \\ Email: kalyanasisbhattacharyya@gmail.com
}

\begin{abstract}
First, this paper identifies education as one of the main livelihood needs of refugee children, but addresses the "knowledge that lies" inherent in the axiological aspect of the context. Second, this article examines a philosophical understanding of an argumentative situation in which the whole problem of children's education reveals a series of gaps in the political and pedagogical value system. And The articles main purpose is to problematize the system of refugee education through the uncertain narratives of cultural relativity. Using a qualitative approach and several data collection techniques such as observation and literature study and interactive analysis, the researchers found that politics plays a major role in education for refugees, their anger and surveillance are very humane, why politics seems so lame cannot act with certainty given the suffering of refugees all over the world, because it is politics that has co-opted and fears social Darwinism in its power narrative
\end{abstract}

Key Words: Humanism, Citizen, Liberalism, NRC, Epistemic Injustice, Axiology, Global Justice.

\begin{abstract}
ABSTRAK
Pertama, makalah ini mengidentifikasi pendidikan sebagai salah satu kebutuhan mata pencaharian utama anak-anak pengungsi, tetapi membahas "pengetahuan yang ada" yang melekat dalam aspek aksiologis konteks. Kedua, artikel ini membahas pemahaman filosofis tentang situasi argumentatif di mana seluruh masalah pendidikan anak-anak mengungkapkan serangkaian kesenjangan dalam sistem nilai politik dan pedagogis. Dan tujuan utama artikel ini adalah untuk mempermasalahkan sistem pendidikan pengungsi melalui narasi relativitas budaya yang tidak pasti. Dengan menggunakan pendekatan kualitatif dan beberapa teknik pengumpulan data seperti observasi dan studi pustaka serta analisis interaktif, peneliti menemukan bahwa politik berperan besar dalam pendidikan bagi pengungsi, kemarahan dan pengawasan mereka sangat manusiawi, mengapa politik tampak begitu timpang tidak dapat bertindak dengan pasti. mengingat penderitaan para pengungsi di seluruh dunia, karena politiklah yang telah mengooptasi dan takut pada Darwinisme sosial dalam narasi kekuatannya.
\end{abstract}

Kata Kunci: Humanisme, Warga Negara, Liberalisme, NRC, Ketidakadilan Epistemik, Aksiologi, Keadilan Global.

\section{INTRODUCTION}

"There will be no loyalty, except loyalty towards the Party. There will be no love, except the love of Big Brother. There will be no laughter, except the laugh of triumph over a defeated enemy. There will be no art, no literature, no science. When we are omnipotent we shall have no more need of science. There will be no distinction between beauty and ugliness. There will be no curiosity, no enjoyment of the process of life ( Quote by George Orwell, 1984 part III, Chapter III )"

As one begins with Orwell's excerpt and then moves on to the next paras one would, at the first instance, be flabbergasted to relate the issue of education for the refugee children with it, but keeping in

* Copyright (c) 2021 Kalyanasis Bhattacharyya

This work is licensed under a Creative Commons Attribution-ShareAlike 4.0 International License.

Received: December 4, 2020; In Revised: January 10, 2021; Accepted: February 8, 2021 
mind the gloomy state of contemporary international politics and then going through the analysis of the political complexities and philosophical contingencies surrounding the lives of the refugees one might finally understand the relevance of it. Nobody can isolate anything from the quagmire of politics not even teaching the children in refugee camps. It is parochial, but it is what it is (Kraus, 2015). The value of education does not need any formal introduction, because it is one of those foundations of our civilisation that it will not be ambitious to attribute the importance of the spread of education to the present culture of peace and cooperation in the international system. Liberalism, the idea of nation-state, global peace and justice, these concepts as the essential categories of modern political system are the yield of the European Enlightenment (Harris \& Morrison, 2012; Saul, 2013). And Enlightenment is a product of education as well as producer of education. Liberal values are to be taught, one is not born with them. A society needs to learn them to cultivate peace. In our time international peace, though not unblemished, is happening because of the liberal culture of the West has asserted itself after learning the value of peace through two big wars. Therefore, it became essential to teach and educate. Interestingly in colonies the subjects were educated to serve the colonial interest. Education has political and utilitarian values attached with it.

If one goes through the data on the number of the stateless people and every other accounts of different categories like asylum seekers or refugees or else one would find that the UNHCR has comprehensively built up the database, but the figures are enough to sadden any soul. A staggering number of people are living under acute compromised state of social living. When we see that approximately 70 million people are suffering because they have been forced out of their own homeland and out of them 20.4 million people are under the mandate of the UNHCR and another 5.5 million are under UNRWA's mandate and combining that only 25.9 million is officially known as refugees, other have no political status and are practically left to fend for themselves (Kaukko \& Wilkinson, 2020). When there are considerable number of research works and care activities are done on and for the refugees we have practically no clue how are these people doing who are not known as refugees, since it is hoped that a social science research ought to spread the culture of empathy among the society. Sympathy does not always help and generally society does not teach to empathise.

However be the political interest education is about training skills and about learning essential values. And values kept on changing through the passage of time (Kende et al., 2017). For the present political culture, economic development is paramount, education is necessary for that. No denying the fact that education is essential for social change (Bordignon \& Moriconi, 2017), it is instrumental for national integration, it is necessary for consciousness. Education can be used for hegemony and counter hegemony as well. Though his research presented a completely different perspective to deal with the impact of education on the children of Bengal Shivaji Bandyopadhyay's Gopal Rakhal Dvanda Samas in Maiti (2016) demonstrates how the language and ideas are used to build myths among the children and cultured them with the Colonial ideas regarding India and the East or the Africa.

In recent developments India has seen much political unrest while implementing the National Citizens Register (NRC) to identify the real citizens (Chapparban, 2020). The ruling government, with a substantial support in the legislature, seemed adamant, at a given point of time, to give effect to this register. The party in power, allegedly known for its religious-nationalist ideological inclinations, the Bharatiya Janata Party (BJP), promised in its election manifesto to introduce this register and in consonance with that the government reintroduced NPR (National Population Register) to develop a database for every Indian resident, citizens and non-citizens as well. And on the 11 $1^{\text {th }}$ of December 2019 through the Citizenship Amendment Act (CAA) the government categorically hinted at leaving the Muslims outside of its new policy to accept the illegal migrants who faced religious persecution which has definitely 
disturbed India's secular credential and was received by nationwide mass protest and acrimony. However, this is India's domestic politics but the notable aspect is that there is a culture of suspicion that unwelcomes those who might enter India to save life. It is very heartening that world's largest democracy India is known for its multicultural social fabric, has resorted to such parochial politics. This domestic culture is very relevant here because international cooperation and brotherhood are based on liberal values and tolerance. Refugees are not welcome in undemocratic atmosphere; the refugees, too, generally prefer liberal democracies, even those who hail from the most autocratic, religious and patriarchal countries (Taylor, 2019).

To write this article the author took help from different brochures and digital resources which and that are the primary resources for this article. All the facts, figures and statistics are vividly available in the websites of the UNO and other relevant specialised agencies like the UNHCR, World Economic Forum and the World Bank. Michel Foucault's (2019) The Will to Knowledge: History of Sexuality, Foucault \& Ewald (2003) Society Must Be Defended: Lectures at the College de France 1975-1976 helped in understanding the idea of biopolitics in the contemporary politics. This article finds a research gap in the understanding of academic institutions' role in empowering or liberating the children's of the refugees to be void. Therefore this article tried to delineate that the idea of education makes the case of refugee's not only that of an epistemic injustice, it also presents paradoxes which puts the lives of the refugees in a permanent state of exception by letting them not being enough political to be treated as citizens and marginalises them to the fringes of human society. But strangely this state of exception puts them at the centre of politics. This article precisely doubts the intentions of a host nation's effort to educate the children of refugees. As we know Germany hosts the maximum number of refugees. The reference of Pakistan is important here, since Pakistan hosts the second largest contingent of refugees after Germany and is not a regular democracy (Goodman \& Kirkwood, 2019). The Afghan refugees had to settle in Pakistan since they are not allowed in Iran and the other territories are not communicable either due to natural causes or because of political disturbance.

\section{RESEARCH METHOD}

This article is based on thought based analysis of the topic of refugee children's education. Since this is neither a policy research article nor any case study based commentary, the author deem it suitable to use mixed methodology with a strong bias on qualitative research methods for the problematisation of education system for the refugee children (Creswell, 2014). This article does not provide any panacea for the education process or antagonises its well-known objectives; neither does it examines how any/many south Asian nations have applied education which is an unalterable social service for the refugee children. This piece of writing explores some of the core questions of education system which contribute to the overall development of an individual as well as proves its utility quotient. When civil society's claim for education for all of its future citizen is an imperative how the refugees, who are not citizens in any sense are being taught the primordial values of social living through education system in a suspended state of socio-political living.

The articles sole purpose is to problematize the system of refugee education through the uncertain narratives of cultural relativity. While from the Foucauldian purview of biopolitics the refugees are indeed legally managed by the liberal democratic state. They are being subjected to the panoptic institutions while they are not legal citizens, but they are maintained through different government agencies like the education system to make meek and law abiding objects. Since their suspended status as refugees do not fulfil the criteria for being state subjects, they are in a permanent 'state of exception'. Which is a political 
idea of Giorgio Agamben. This article shall try to contextualise biopolitics of these two great thinkers while examining the case of refugee education. Therefore, it is a philosophical attempt to delve into the different strands of the idea of educating the refugees and its probable real-world outcomes (Jones et al., 2017).

\section{RESULTS AND DISCUSSION}

\section{Result and Theoretical Framework}

This article will seek to explore different aspects of bio politics and governmentality. Refugees are at the centre of a spectrum of problems. Apart from their own demands and problems regarding the basic needs of livelihood like food, shelter, health and other requirements of a civil life they are seen and are felt as intruders by the host country as well. After the Syrian crisis as the stateless peoples reached the different countries of Europe the Islamophobia has made situations worse for the migrants to settle peacefully in a foreign country. Series of riots took place in different parts of European nations (Bose, 2020). However, the political leadership has somewhat successfully arranged their settlement on war footings. The internal factors are very essential for the migrants' settlement. There was strong opposition from many nations to accept the migrants. Islamophobia or Xenophobia whatever be the name, there are enough reasons for the citizens to react this way, since there have been series of terror attacks in many parts of Europe, and that too conducted by different Islamic organisations. Some children of immigrants to western diaspora, insufficiently integrated into the host society and being caught between two cultures, have, in a search for identity and meaning, looked at jihadists as role models and thousands of them have migrated to Syria to become foreign fighters (Schmid, 2016).

It is never easy to win trust from the common people when it comes to accept people from different cultural background. It is a great work of cultural exercise by the political class to endorse the illegal migrants. Neither the common people of any host nation nor the refugees are reasonably tolerant and politically conscious to understand each other's circumstances. When a host nation provide the refugees with an area to live they gradually assert their social existence. Once their demands for food and shelter are politically organised they generally start political movements for other socio-political needs. Many host countries do offer education and employment related facilities, but such services do not come easily. Economic constraints has to be considered for that. Sovereignty is something which is often seen as something in danger or in disturbance while dealing with the refugees. Sovereign is not bound in any way to serve the refugees unless it has that ethical compulsions in its political culture (Cherniavsky, 2017).

It is a humanitarian culture which exists only on an international cooperation basis and are founded on such noble values of universal brotherhood. There may be international covenants on helping the stateless peoples, but that is followed for the sake of international peace and justice. Just to avoid some sort of anarchy (Carter, 2013). If the refugee settlement challenges the sovereign through internal disturbance it could ultimately fail the 'so called' peace which is operational for the last 70 years. Such realist propositions sounds very base and gives a smack of gun powder but the world system under the aegis of the UNO is surviving because there is a mutual consent for peace but not denying the realist perspectives, i.e. any challenge to the sovereignty could destroy this internationalism. And it is dwindling if one sees the recent developments of refugee crises in the aftermath of the Syrian mass exodus. One can remember how the US closed down many of its shelters for refugees which were built up during the era of Barrack Obama.

One can see how Poland, which had been through the grim realities of the holocaust has refused to accept refugees after letting few of them in. Greece, Germany and France are dealing with the major portion of that mass of stateless people (Wennersten \& Robbins, 2017). There are incidents of riots and 
other violent crimes in these nations. There are cases of terrorist attacks as well. But still these nations don't falter from their commitment to global peace and to universal brotherhood. Such narratives definitely have counter narratives as well. Refugees do not bother about international law and its suggestions for refugee settlement. They only care for living, they have fled their motherland to save their life and their families. They do not get equal treatment everywhere.

The following figure 1 show the steady decline in the intake of refugees by the United States of America. Globally, 92,000 refugees were resettled in 2018, down from 103,000 in 2017 and a peak of 189,000 in 2016. The decrease occurred despite an increase in the world's total refugee population in 2018, when it reached a record 20.4 million, according to UNHCR (2001).
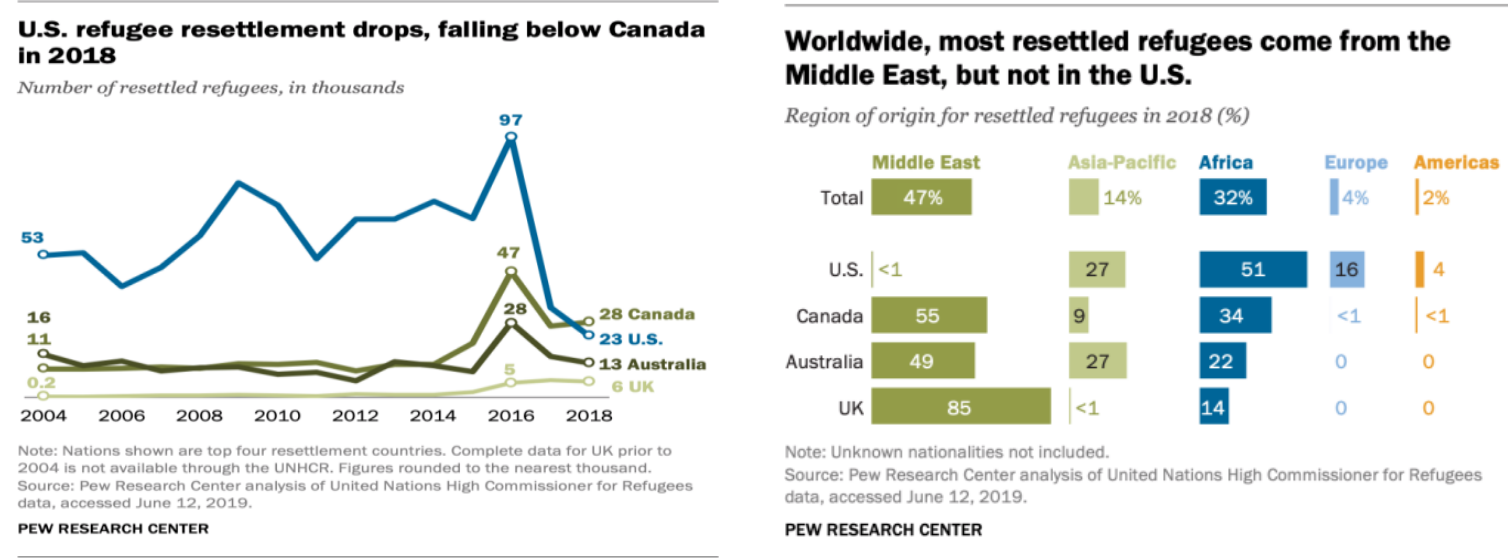

Figure 1. steady decline in the intake of refugees by the United States of America

\section{Analysis}

Many countries today face this increasing challenge of accommodating, adopting and providing for such afflicted populations with limited resources. Usually children being most vulnerable bear the brunt of such human catastrophes. The Universal Declaration of Human Rights Article 14 (1) states that "everyone has the right to seek and to enjoy in other countries asylum from persecution (Kinzie et al., 1990).

During the last decade more than two million children have been killed in conflict, with a further six million wounded and one million orphaned.

If we clearly and categorically contextualise the issue of the refugee children's education we have to explain each topic separately. Like 'who are the refugees', 'why do they need education', 'what is education', 'is the education system based on social justice' and so on. Such way of exploring things are deeply rooted with the basic questions of philosophy. What is something and why we need that etc. there are metaphysical questions but they are not out of the world or abstract things. These questions are about delving deep into the existence of the very idea of something. Analysing the major concepts of the matter of contention shall help to understand the locus of the issue in the cobweb of conflicts, slippages and traces. Empirical understanding can be questioned on the grounds of epistemic, positional and cultural relativity, subjectivity and this article wishes to identify the inherent contradictions, paradoxes and traces related to the idea of education system which is meant for the children of the refugees (Todd, 2015).

Through an empirical survey a research team can identify the day to day problems and other aspects of the education policy of some refugee camps in some given territory of the world. But through theoretical analysis and hermeneutic exploration one can identify the prominent areas of the epistemology 
of this specific education system. This theoretical experiment can be done employing different theoretical tools. This article identifies the proximity of biopolitics to better understand the situations that the refugees are through facing the grim realities in different parts of the world. And biopolitics of Michel Foucaul (2019).

The state and the sovereign has always wanted to control the human body and mind. State has the objective to create meek subjects to control them according to its will. And there has to be a power narrative which shall explain everything regarding what one has to do with his body. The state has employed different machineries to that end. Beginning from the family an individual is screened, restricted and controlled by different social institutions. Individual is the end result of this series of regulation and checks. Michel Foucault has specifically hinted at the roles of the health care institutions and mad houses in controlling the human body.

Government needs the subjects who shall understand that their wellbeing is government's concern. Government introduces the individual with different vigilant mechanism through which the state keeps track of the individual's whereabouts. State spreads awareness regarding the economy, national prosperity, development among its citizens and inspires them to take part in that. School, college, universities, hospitals, other offices are the institutions where citizens are kept under surveillance as well as they are being instructed how to take part in the national progression programmes (Foucault, 2019). A modern state is capable of coercive forces but it does not want to apply that. It ensures citizens' complete submission through different institutional propaganda. So, broadly there are three important aspects as are being explained by Michel Foucault which are relevant to the present article. Firstly the sovereign, i.e., the state which is very concerned about its power over its subjects. So it employs institutions to teach governmentality to its citizens to ensure their voluntary submission (Foucault, 2019).

Knowledge holds the key to power, and the sovereign has its own narrative of power which it teaches to its citizens very subtly through different institutions to make them meek and submissive. Lastly there are the instrumental arrangements for the delinquents to get punished. This institutions again has earned the legitimacy through the popular mandate, mostly. Foucault has explained this taking examples from the mediaeval period but the modern state has similar mechanisms using subtle conduct. For example prison which helps the law-breakers to get reformed, to be law abiding citizen. Democratic morality believes in such institutions however, it does believe in corruption in institutions and therefore it suggests introducing reformations; but keeping the basic structure ideologically intact. Nobody seems questioning the hegemonising role do such institution play in the society. In the next segment the Foucauldian idea will be discussed further (Foucault \& Ewald, 2003).

For Giorgio Agamben refugees are the ones who have no relevance with all legal and political categories associated with the idea of sovereignty, such as people, public, citizen and human rights:

'the refugee' can be represented as the paradigmatic site - and victim - of modern techniques of what Michel Foucault called 'governmentality': the organised practices and techniques used to produce, care for and/or dominate individual subjects (Owens, 2009)". Agamben says refugees can be seen as the ultimate 'biopolitical' subjects who can be governed at the level of population in a permanent 'state of exception' outside of the general legal system. In the incarcerated camp life they are 'reduced to 'bare life': humans as animals in nature without political freedom.

\section{Discussion}

If we categorically discuss the case of the refugee children's education while discussing the notions of sovereignty and the discourse of 'power' of Michel Foucault and Agamben, apparently that might seem 
as category mistake, since the refugees are not state subjects and sovereignty is exclusive to a state (Ongur \& Zengin, 2019). To argue this case one has to understand the epistemology of the Refugee. They are stateless, they are no longer under the legal control of their nation of origin, and their nations do not seek to repatriate them either, so they are not state subjects. True, but they are not beyond the control of any state power. They are taken care of by the host nation, where they have come to stay. The host nation does intricate profiling of the refugees before giving them shelter. It keeps all statistics and then let them stay in some camps with proper surveillance. Their presence makes the host uneasy owing to various factors ranging from economic to political, social, cultural, environmental even biological (Black, 2018). Therefore, the host nation has to employ its administrative machinery to maintain this assemblage. So the host which is a sovereign power - exercises its control over this contingent of people who are not its legal responsibility.

To exemplify the argument two different incidents are presented here. Let us see a news briefing on the state of the refugees who are living in Germany. On the occasion of World Refugee Day on $20^{\text {th }}$ June 2020 German Foreign Minister Heiko Maas has called for greater protection for the refugees while expressing his grief at the staggering number of total displaced people. He has expressed his anxiety over the cramped condition of the refugee camps and was aware of the fact that the pandemic condition has made situation worse for the refugees, since social distancing and other precautionary measures to fight the spread of the corona virus is quite impossible in those camps. He wished that the other European nations, whom he has called as partners, should be careful about the movements of the refugees in this pandemic conditions when the international borders are mostly closed. That such conditions should not make their living more challenging, he urged that shelters for the refugees should remain available. In the same news bulletin the Council of the Protestant Church of Germany has urged the German people to help the refugees by giving them money and by praying for them. The Church Council as well as the Foreign Minister both wanted the refugees should live a dignified life (Guardian, 2020).

It is undoubtedly a good news for the refugees, because the political institution and the ecclesiastical institution both have requested the people to help the refugees and express solidarity with them. But this news brief clearly indicates that the refugees are staying inside the political boundary of a state, and the Foreign Minister, a political representative of the sovereign, who in no way is dependent on the mandate of the refugees to remain in power, but is working for their wellbeing and dignified living. Liberal thinkers and peace studies' expert can identify these acts as the international responsibility of a liberal democratic state. However, one has to admit that the day to day life is dependent on the policies and exchequer of the host nation. In case of any law and order situation the host nation sends police and other enforcement agencies to the refugee camps.

The host nation looking after their health, education, and other welfare issues. When the minister expressed the importance of a living with dignity he certainly talking about civil rights and liberty issues. International responsibility for humanitarian aid to humanity and commitment to global peace and brotherhood might be the reason that a nation let the displaced people into its political territory and they get financial support from the international organisations, but they themselves generating fund as well and one can understand how these people can be the subjects of the coercive machinery of the host nation at any given point of time (Hassan et al., 2016). Another reference of an incident can be seen as sufficient reason to understand that the state can easily put coercion on the displaced people if it so desires and no agency or anything can make any difference. On 31st January 1979 the Government of West Bengal, a federal unit of India, in a bid to evict a large contingent of refugees (approximately 40,000) from an island of the Sundarbans, a legally protected reserve forest land called Marichjhapi, used its police force. After an 
economic blockade and complete isolation the government machinery opened gunfire which ended up a bloody affair as commentators claimed that hundreds of unarmed people were brutally killed, burnt alive and their properties were vandalised by the state police.

The government records show only two deaths but the news media and the opposition parties claimed it was a massacre. The ruling government of the state had no problem either national or international to retain its rule. Therefore, the claim of this article that the displaced people are living a life almost like citizens, but whether they are entitled to enjoy the civil liberties that completely depend on the host nation's political intentions. Now, form the Foucauldian perspective the children of the refugees can be put under the educational regimen to make meek and governable subjects whom the sovereign can mould and direct according to the situation demands. Education can be used as an excellent tool for the purpose of discipline. The contemporary situation when the deadly virus Covid-19 has killed more than 480,000 people all over the world, a government with malafide intention can isolate any refugee camp and can make them suffer in pretence of anti-pandemic measure. Refugees generally live in designated, specified area. They do not enjoy the right to free movement, they do political rallies and movements, but generally their demands don't get any day light. Hence, Agamben's idea of a bare life becomes relevant here. The people of the camps have no political life, but they are central to political powernarrative (Woods et al., 2020).

Western Philosophy's bias with the binary of Political life and Private life is very old. Since the Greeks' political life in the politics of the Polis to the analysis of Hanna Arendt or Giorgio Agamben. But when the Zoë was excluded from the political life in the ancient ideas the modern state has zoomed in on the 'life' itself therefore making the distinction between the Zoe and Bios rather blur. In the case of the refugees these non-citizens are a very part and parcel of the state politics, however, they do not enjoy the civil rights. Their political strife is to get into the political system through different political mobilisation keeps them a steady subject in the contemporary power narrative.

Children are not logically responsible for their status of a refugee. They cannot take the onus for being stateless, they are neither consciously aware of this political status or they have generally any direct causality referential liability for their life in a refugee camp. Similar or rather more strange the case of those who are born in the camps. Who is to blame for the tragic and horrid lives of these children? Before becoming politically aware they cannot relate motherland/fatherland/homeland or the suspended status of their political life in a host nation. On a mundane life how would they understand the reason of discrimination they face in a society where they live on the fringes? Modern nation-state has applied a kind of 'teleological suspension of the ethical' while treating with them ${ }^{4}$. While thinking about their education the host nation would definitively be thinking about the future yield of such programme. If the refugees enter into the job market the citizens will not be happy, which will never be a good news for the government in power. But the host nation cannot deny educating them fearing in the absence of education the young children of the camps might fall prey to the socio-political evils. They might lead unhygienic life which can disturb public health, can populate the underworld which can even end up joining in the terror camps. Therefore, education is crucial even for such a 'permanent state of exception' which might not produce any economic yield but can still hegemonise them toward becoming meek and docile political subjects and thus, the Polity ensures governmentality.

A photograph of the corpse by Nilüfer Demir made global headlines after the child drowned on in the Mediterranean Sea. He and his family were Syrian refugees trying to reach Canada via Europe amid the European refugee crisis. They were being taken to Europe by some illegal immigration dealers. This child died with his mother on that night. They boarded on a plastic boat with a capacity of eight people but it 
had sixteen people on it fitted with fake jackets which seemed like real life jackets, they were desperate to flee for life. But the boat had capsized in the Mediterranean Sea just after setting sail. In 2015's Canadian election this tragedy suddenly became a political agenda and cause mutual mud-slinging between the major parties for not honouring the refugees in present and in past, and series of efforts were made to bring that family in Canada.

Such politics adds to that tragedy since it is not about that child's family only, there are hundreds and thousands like him, dying as soft targets. While dealing with the refugees why do not people remember this tragedy why they stick to remembering the riots and other mob violence which occurred after the refugees reached the European shores? Their rage and demand for life is very human, why politics seems so lopsided. This conclusion cannot act conclusively while keeping in mind the agonies of the displaced people all around the globe, because it is politics that has co-opted and substantiated social Darwinism in its power narrative. Muhammad Amin, a young poet and is a winner in the Timothy Winters challenge on Young Poets Network has written a poem on young Aylan. Quoting that poem is befitting here as a tribute to that tragedy and of course can make a perfect political narrative for millions of children whose dreams are being buried every day in different unknown shores:

Alan Kurdi
Alan Kurdi lies on the beach
Like autumn's fallen leaf
Seagulls soar in the sky
Singing a song of grief
His eyes are bright pools
Swimming in the deep
Are forgotten faces full
Of pain, faces that weep
Alan Kurdi doesn't breakfast
No sugar puffs or corn flakes
Snap, crackle and pop. Bombs
Fall like little earthquakes
He has never played nintendo
Nor xbox, truth or dare
Only hide-and-seek with IED's
Landmines and the snipers stare
The water lapping at his feet
His body lies on the sand
Still, silent, frozen, frail
A ragdoll from another land
Alan Kurdi's voice reaches me
“Amin, Amin listen to me
I was put into the sea
Like Moses. Don't you see?

(Quote by Muhammad Amin ) 


\section{CONCLUSION}

Education positively takes into account civilization and the values closely built on the basis of humanism. Liberal nations emphasize universal education. However, many things stumble upon the Citizenship question. Whether refugee children have the same claim to education creates a strange situation. The political role is very large here, proper education for refugees can only occur if it is supported by a strong political system and supported by the economy of the host country, unfortunately there are still around 70 million people suffering because they have been forced out of their own homeland and from them 20,4 million people are under the UNHCR mandate and another 5.5 million are under the UNRWA mandate and combine that only 25.9 million are officially recognized as refugees, others have no political status and are practically left to fend for themselves. When there is a fair amount of research work and care activities being done and for the refugees, we practically don't know how these people are doing who are not known as refugees.

\section{DAFTAR PUSTAKA}

Black, R. (2018). Refugees, environment and development. Routledge.

Bordignon, M., \& Moriconi, S. (2017). The case for a common European refugee policy. Bruegel Policy Contribution.

Bose, P. S. (2020). The shifting landscape of international resettlement: Canada, the US and Syrian refugees. Geopolitics, 1-27.

Carter, A. (2013). The political theory of global citizenship. Routledge.

Chapparban, S. N. (2020). Religious Identity and Politics of Citizenship in South Asia: A Reflection on Refugees and Migrants in India. Development, 63(1), 52-59.

Cherniavsky, E. (2017). Neocitizenship: political culture after democracy. NYU Press.

Creswell, J. W. (2014). A concise introduction to mixed methods research. SAGE publications.

Foucault, M. (2019). The history of sexuality: 1: the will to knowledge. Penguin UK.

Foucault, M., \& Ewald, F. (2003). "Society Must Be Defended": Lectures at the Collège de France, 19751976 (Vol. 1). Macmillan.

Goodman, S., \& Kirkwood, S. (2019). Political and media discourses about integrating refugees in the UK. European Journal of Social Psychology, 49(7), 1456-1470.

Guardian, T. (2020). World Refugee Day: German foreign minister calls for greater protections for refugees. Www.Dw.Com. https://www.dw.com/en/world-refugee-day-german$\% 09$ foreign-\%09minister-calls-for-greater-protections-for-refugees/a-53882296

Harris, I. M., \& Morrison, M. L. (2012). Peace education. McFarland.

Hassan, G., Ventevogel, P., Jefee-Bahloul, H., Barkil-Oteo, A., \& Kirmayer, L. J. (2016). Mental health and psychosocial wellbeing of Syrians affected by armed conflict. Epidemiology and Psychiatric Sciences, 25(2), 129-141.

Jones, H., Saltus, R., Dhaliwal, S., Forkert, K., Davies, W., Gunaratnam, Y., Bhattacharyya, G., \& Jackson, E. (2017). Go home?: The politics of immigration controversies. Manchester University Press.

Kaukko, M., \& Wilkinson, J. (2020). 'Learning how to go on': refugee students and informal learning practices. International Journal of Inclusive Education, 24(11), 1175-1193.

Kende, A., Lantos, N. A., Belinszky, A., Csaba, S., \& Lukács, Z. A. (2017). The politicized motivations of volunteers in the refugee crisis: Intergroup helping as the means to achieve social change.

Kinzie, J. D., Boehnlein, J. K., Leung, P. K., Moore, L. J., Riley, C., \& Smith, D. (1990). The prevalence of posttraumatic stress disorder and its clinical significance among Southeast Asian refugees. The American Journal of Psychiatry.

Kraus, K. (2015). The Last Days of Mankind: The Complete Text. Yale University Press. 
Maiti, S. (2016). The Art of Storytelling and the Role of Memory in Salman Rushdie's Haroun and the Sea of Stories and Luka and the Fire of Life. Rupkatha Journal on Interdisciplinary Studies in Humanities, 8(1), 206-213.

Ongur, H. Ö., \& Zengin, H. (2019). Reading Agamben backwards: Syrian refugees, biopolitics and sovereignty in Turkey. Social Science Information, 58(1), 103-120.

Owens, P. (2009). Reclaiming 'bare life'?: Against Agamben on refugees. International Relations, 23(4), 567-582.

Saul, J. R. (2013). Voltaire's bastards: The dictatorship of reason in the West. Simon and Schuster.

Schmid, A. P. (2016). Links between terrorism and migration. International Centre For Counter Terrorism (ICCT) ICCT Research Paper.

Taylor, A. (2019). Democracy May Not Exist, But We'll Miss it when It's Gone. Metropolitan Books.

Todd, S. (2015). Toward an imperfect education: Facing humanity, rethinking cosmopolitanism. Routledge.

UNHCR. (2001). Statistics. http://www.unhcr.ch/statist/main.htm

Wennersten, J. R., \& Robbins, D. (2017). Rising tides: climate refugees in the twenty-first century. Indiana University Press.

Woods, E. T., Schertzer, R., Greenfeld, L., Hughes, C., \& Miller-Idriss, C. (2020). COVID-19, nationalism, and the politics of crisis: A scholarly exchange. Nations and Nationalism. 